\title{
"CERVEZA STOUT PARA HOMBRES Y CERVEZA LAGER PARA MUJERES”: UN ANÁLISIS DEL LENGUAJE SEXISTA Y ESTEREOTIPOS DE GÉNERO EN TEXTOS DE ENSEÑANZA DEL IDIOMA INGLÉS UTILIZADOS EN CHILE*
}

\author{
"STOUT BEER FOR MEN, AND LAGER BEER FOR WOMEN": \\ AN ANALYSIS OF SEXIST LANGUAGE AND GENDER STEREOTYPES \\ IN ELT TEXTBOOKS USED IN CHILE
}

Sofía Mackarena Muñoz González **

\section{Resumen}

El presente estudio trata sobre el lenguaje sexista y los estereotipos de género en los libros de texto de enseñanza del idioma inglés (ELT), utilizados en primer año medio de la educación secundaria en Chile. Enfatiza la idea de que los libros de texto de ELT influyen en las opiniones y conductas de los y las estudiantes. Los libros de texto desempeñan un papel importante en el aprendizaje de la cultura y su idioma y deben motivar y alentar a los/las alumnos; por lo tanto, es importante que ambos géneros estén igualmente representados. Este estudio se basa en una investigación de métodos mixtos y examina dos textos escolares: Teens in Motion 1 y Solutions Pre-Intermediate.

\footnotetext{
* Thesis submitted in partial fulfillment of the requirements for the degree of Master of Arts in TESOL. This program of studies and thesis were founded by the Comisión Nacional de Ciencia y Tecnología de Chile (CONICYT) Programa Formación de Capital Humano Avanzado. Beca de Magíster Nacional / 2017 - 22170345

** Licenciada en Educación, Magister en Enseñanza del Inglés como lengua extranjera, Instituto Profesional Virginio Gomez, Chillán. email: sofia.munoz2@virginiogomez.cl, ORCID https://orcid.org/0000-0002-9088-5206
} 
Los resultados indican que se observa una brecha de género en ambos textos; los personajes masculinos están más presentes y son más importantes que los femeninos; los varones presentan roles más activos y las mujeres presentan roles pasivos y socialmente aprobados.

Los resultados de esta investigación permiten proyectar la necesidad de nuevos estudios que den continuidad a las miradas analíticas abordadas. Para esto, es interesante problematizar otros libros de enseñanza del idioma inglés utilizados en Chile.

\title{
Palabras claves:
}

Educación, feminismo, género, inglés, cultura, discriminación.

\begin{abstract}
The present study deals with how sexist language and gender stereotypes are embedded in English language teaching (ELT) textbooks used in the eleventh grade of secondary school in Chile. Textbooks play an important role in learning a culture and its language and they should motivate and encourage that both genders be equally represented.

The study underscores the idea that ELT coursebooks influence students' views and behaviours. This study draws on a mixed methods research and examines two coursebooks: Teens in Motion 1 and Solutions Pre-Intermediate. The results suggest that gender bias does exist in both textbooks series; male characters are much more frequently presented and portrayed as more important than females in both textbooks. Also, males are portrayed as more active and successful, while females as more quiet with socially approved roles, and taking disadvantaged positions.

Further research is required in the area of how language and gender representation are presented in others ELT textbooks used in Chile is therefore suggested to confirm the results of this study, further research that addresses the different approaches to teaching non-sexist language are also needed.
\end{abstract}

\section{Keywords:}

English, education, feminism, gender, power, sexism. 


\section{Introduction}

During the 1960s, the feminist movement fought against gender stereotypes and sexism, which raised awareness about gender equality in textbooks. In other words, the feminist movement is the entrance for studying sexism and its relationship with language. During the 1970s, the study of sexism in English language textbooks is put on the spotlight through the publication of Hartman and Judd's (1978) "Sexism and TESOL Materials"; Hellinger's (1980) "For Men Must Work, Women Must Weep: Sexism in English Language Textbooks Used in German Schools"; and Porreca's (1984) "Sexism in Current ESL Textbooks". From these studies on, several scholars around the globe have been starting to realize about gender disparity and putting the focus on this topic. Hence, Xiaoping (2005) pointed out that it is important to expose students in a more neutral way that allows them to form their own images of males and females (as cited in Emilia, Yunita, \& Laela, 2017, p.207), otherwise, we could expose them to experience "feelings of exclusion, devaluation, alienation and lowered-expectations" (Gharbavi \& Mousavi, 2012, p.42). Accordingly, the two principal themes in this study are: sexist language in English language textbooks and gender stereotypes in English language textbooks.

\section{Literature Review}

\subsection{The Feminist Movement}

The feminist movement legitimized women's rights by making gender discrimination visible and raising awareness among women's communities. One example of promoting awareness of gender issues was to determine gender stereotypes as used in language. Gender stereotypes are identified as "beliefs about the characteristics and behavior of each sex" (Manstead \& Hewstone 1995, p. 256). Those beliefs are "widely shared" among members of a culture (Etaugh \& Bridges, 2010, p.28). In other words, gender stereotypes 
are a reflection of society and exaggerate the differences between females and males. During the 1970s, the feminist movement opens the door for sociolinguistics studies which determine how language is used as an instrument to discriminate and dominate females (Key, 1975; Lakoff, 1975). During the 1990s women's studies became established as an academic field throughout sociolinguistics, and one of the major issues in sociolinguistic research is the relationship between sex and language. This idea provides a basis that claims that language can reinforce the idea of male dominance and superiority and female inferiority (Ansary \& Babaii, 2003). All in all, feminist movement, from the academic arena, has contributed greatly to the society's awakening on how curricula and coursebooks reproduce gender discrimination.

\subsection{Sexist Language}

For decades we have been told that certain forms of language are more appropriate for men, such as swear words or insults, while other forms of language seem more appropriate for women, for example, expressions denoting feelings and emotions. It is, therefore, necessary to understand what sexist language is. The term sexist language or gender bias occurs when a certain gender is exploited unfairly and discriminated through the use of linguistic resources (Yonata \& Mujiyanto, 2017). According to Hyde (1984), sexist language can be defined as "the notion that the English language contains sex bias, particularly in usages such as "he" and "man" to refer to everyone" (p. 607). Thus, sociolinguistic studies deal with the relationship between sex and language and how this common bond is represented in language.

\subsection{Gender Stereotypes}

Stereotypes of all forms have been fostered in English language materials from very early on. Consequently, it is crucial to explore what gender stereotypes really are. According to Ruby (2016), "gender stereotypes not just simply reflect, but also overemphasize, 
the existing differences between males and females" (p. 676). In other words, gender stereotypes are the exaggeration of the differences between males and females in their behaviors. Thus, gender stereotypes are a set of beliefs about the aspects and attitudes of each sex which take concrete behavioral forms. These assumptions are "widely shared" across the cultural codes in society (Etaugh \& Bridges, 2010). In this respect, language textbooks, as cultural artifacts, can serve various purposes by portraying female characters in English language textbooks in particular forms, which can ultimately set beliefs about the aspects and attitudes of each sex which take concrete behavioral forms.

\subsection{Role of English Language Textbooks: Influence on Students}

Brugeilles and Cromer (2009) conceive of a textbook as "the core learning medium composed of text and/or images designed to bring about a specific set of educational outcomes; traditionally a printed and bound book including illustrations and instructions for facilitating sequences of learning activities" (p. 14). Accordingly, English language textbooks are one of the most important tools used by teachers on a regular basis, and similarly, coursebooks are the material to which students are most exposed. By drawing on the negative effects that gender stereotypes have, Hamilton, Anderson, Broaddus \& Young (2006) warned that "stereotyped portrayals of the sexes and underrepresentation of female characters contribute negatively to children's development, limit their career aspirations, frame their attitudes about their future roles as parents, and even influence their personality characteristics" (p. 757). Since gender stereotyping in education perpetuates inequality between women and men, the elimination of gender-stereotyped messages in English language texts is vital.

2.5 CDA Studies on Sexism and Gender Stereotypes in English Language Textbooks

Critical discourse analysis (CDA) emerged in the 1970s and provides 
a critical perspective towards society (Rahimi \& Sahragard, 2007). According to Rahimi and Sahragard (2007), CDA has the aim of investigating "the power relations, ideological manipulations, and hegemony" (p. 1). In other words, CDA is an approach used to analyze in depth any type of written or spoken material in order to make sense of the way in which discourses of power manipulate the reality in the society for its own purposes and thereby attempt to encourage the victims of such dominant discourses to be aware of it and transform their lives.

Research in the field of discourse has revealed many examples of inequality between female and male characters in English language textbooks (e.g. Hartman \& Judd, 1978; Porreca, 1984; Coates, 1986; Poulou, 1997; Hellinger \& Bußmann, 2001; Mineshima,2008; Mukundan \& Nimehchisalem, 2008; Amini \& Birjandi, 2012).

For instance, the study conducted by Hartman and Judd (1978) indicated first that female and male genders were regularly portrayed in stereotypical roles; and second, that the English language itself contains a sex bias and uses the masculine generics like man to refer to the whole population. In contrast, Porreca's model (1984) has been used until now to examine English language textbooks and their illustrations, in order to determine sexism. She concluded that "there is evidence that sexism continues to flourish in ESL textbooks" (p. 718). Similarly, in the present century there have been prominent studies in the field of sexism and gender stereotypes in ELT (e.g., Hamilton et al., 2006; McGabe, Fairchild, Grauerholz, Pescosolido, \& Tope, 2011).

Hamilton et al. (2006) examined 200 award-winning children's picture books and they reported that books contained twice as many male characters as female characters. McGabe et al. (2011) analyzed approximately 6,000 books published in the United States. The researchers focused their analysis on the representation of males and females in titles and main characters. They concluded that children's books are twice more likely to feature a male central character than a female main character. It seems to be that almost everything revolves around men and their dominance even language due to the fact that language sometimes is used to diminish women. 
In this respect, how is English sexist? The extent to which the English language system is sexist is reflected in the way in which its lexis contains terms that reflect sexism. Researchers such as Hartman and Judd (1975), Graham (1975), Nilsen (1977) and Porreca (1984), analyzed six categories looking for sexism and gender stereotypes in language. These categories are: omission, firstness, occupations, the frequency of male nouns to female nouns, female-exclusive masculine generic constructions, and the types and frequency of adjectives for men and women.

\section{Methodology}

This paper discusses the preliminary analysis of the study and addresses these research questions:

1) How the language used suggests a notion of sexism?

2) How the images portray gender stereotypes?

In determining what the categories are being used in this study, the methodological framework proposed by Hellinger, 1980; Porreca, 1984; Amini and Birjandi, 2012; Barton and Sakwa, 2012; Gharbavi and Mousavi, 2012 is employed. The notions of sexism in English language textbooks are analyzed across five categories including visibility, firstness, occupations, masculine generic constructions and activities associated with female and male characters. The analysis of the first question includes the quantitative statistical results from ELT texts used in the analysis and then discusses the qualitative findings throughout an in-depth interpretation of the discourse (CDA). Moreover, a case study content analysis approach involved gathering information that enabled the researcher to focus in depth on specific instances of sexist language such as visibility of female and male characters, (firstness) which is the practice of persistently ordering males or females first in the school texts, occupations in which females and males were depicted, and the type of illustrated and textual activities in which females and males participated. 
On the other hand, to examine how gender is portrayed in illustrations, a visual interpretation of the illustration in the texts was necessary in order to explore the power of images and how these can be understood. Thus, this study involves Bell (2001) and Kress and van Leeuwen (2016) who argue that visual content analysis is focused on both the content and expression of images and it can be applied for quantitative analysis and a qualitative semiotic study. In the English language arena, Ruby (2016), conducted a study that involved the analysis of how gender is represented in illustrations of ELT books in terms of their hair length and clothing. Likewise, a semiotic interpretation of the illustration in the texts was necessary in order to explore the power of images and how these can be understood. Semiotics is a philosophical approach to research mediated by the use, and interpretation of signs, images and symbols (Kress \& van Leeuwen, 2016). Images are means of communication intended to interpret messages of what people do or say. In this respect, the illustrations are categorized analyzing the participants in each image (who), the actions (what is happening) and the circumstances (where) (van Leeuwen 2008). At the same time the study examined hair length (long hair, below the shoulders/short hair, if it just reaches the neck), color clothes (light colors for female or dark/opaque colors for male) and clothing specifically in women (skirts, dresses and trousers), facial features, etc.

\subsection{The Sample and The Corpus}

The study focused on a corpus of books designed to teach the English language in eleventh-grade of secondary school in Chile. The book 1, is distributed by The Ministry of Education in rural and urban areas throughout the country. The book 2, published by Oxford University Press is used in a bilingual private school located in Chillán. These school texts are the following:

- Book 1: Polk, J. (2017). Teens in motion 1, Primero medio: Student's Book. Santiago: Ediciones Cal y Canto.

- Book 2: Davies P. and Falla T. (2017). Solutions 3rd Edition Pre-Intermediate: Student's Book. España: Oxford University Press. 
Due to the length of the units in both coursebooks, two units and five audio scripts from each book were randomly selected. Images containing females and males were only examined if people were shown clearly. Additionally, non-human characters were also excluded from this study.

\section{Data Analysis Procedure}

Due to the nature of the data, which is qualitative and quantitative, and due to the overall approach used to answer the research questions (CDA), the procedure used to analyze the data rests on the guidelines provided by CDA, which looks for manifestations of gender bias and inequality at two levels: The micro level deals with the vocabulary/lexis/language, and macro level with whatever surrounds the text such as illustrations, graphic designs, color, size, etc. (Parham, 2013). The corpus developed for this study was examined at both levels. As suggested by Hodkinson and Hodkinson (1999), the study follows stakeholder research model, where the notions of sexism in English language have been studied across categories including visibility/omission and number of interventions in dialogs of females and males in audio scripts, firstness, occupations and roles, grammatical gender (gendered words). Those categories are based on previous studies and articles (Porreca, 1984; Mustedanagic, 2010; Amini \& Birjandi, 2012; Barton \& Sakwa, 2012; Gharbavi \& Mousavi, 2012) and they are described below.

- Visibility/Omission of females and males in language and illustrations.

- Female/male firstness. This is the number of times when females or males are presented first in the school texts. Firstness specifically refers to the mention of men first in books before women.

- Occupations/Roles/Activities in which females and males were depicted.

- Grammatical gender (gendered words). It is a system in the grammar of some languages in which nouns are classified in three gender categories; masculine, feminine, and neuter, as is the case 
of English, Spanish, German and French, which have grammatical gender. Mustedanagic (2010) holds the view that "there is a tendency to separate words depending on the persons' sex which can be spotted in words such as waiter and waitress, steward and stewardess" (p. 31).

Furthermore, the present study seeks to obtain in-depth insights into how males and females are represented in the illustrations of ELT texts by examining the following coding categories: participants in each image (who), actions (what is happening) and circumstances (where) (van Leeuwen 2008). As it was mentioned previously, gender representation in illustrations also may be studied examining, hair length, color clothes and clothing specifically in women.

\section{Findings and Discussion}

\subsection{Research Question 1: How the Language Used Suggests a Notion of Sexism}

\subsubsection{Visibility/Omission}

The first category under study is visibility/omission, which implies the prioritization of one gender over another resulting in specific perceived power relationships and gender discrimination. Tables 1 and 2 present the number of occurrences of female and male appearances both in illustrations and in texts. Table 1 corresponds to the analysis of the school book Teens in Motion 1 (Book 1) and Table 2 shows the results of the examination of Solutions Pre-Intermediate coursebook (Book 2).

As can be seen in Book 1, the number of female appearances in illustrations surpasses the number of male appearances as far as illustrations go, while the textual presentation of female and male is virtually the same. On the other hand, the analysis in book 2 has shown the opposite: The number of female and male appearances is almost the same. However, in the case of texts, the number of male 
appearances exceeds the number of female appearances. This may be due to the fact that during the 1990s, ELT publishers reached a consensus on the importance of developing neutral ELT textbooks. As Gray (2002) argues, this agreement has to do with inclusivity and it "refers to the need for a non-sexist approach to the way in which men and women are represented throughout the coursebooks" (p. 157). Thus, textbook developers prioritize those aspects that point out the obvious making any possible cases of gender discrimination less noticeable. Porreca (1984) emphasizes very clearly the hidden message when females do not appear as often as males, whether on images or language and almost implying that women are not as important as men. Throughout history, women have been portrayed as being dependent on men, submissive or treated as objects/trophies making them less worthy of inclusion in society.

Table 1. Visibility/Omission: Visual and Textual Presentations of Females and Males

Book 1: Teens in Motion 1

\begin{tabular}{lcccccc}
\hline & \multicolumn{3}{c}{ Presentations in Illustrations } & \multicolumn{3}{c}{ Presentations in Texts } \\
\hline & Total & Female & Male & Total & Female & Male \\
Number & 72 & 41 & 31 & 77 & 39 & 38 \\
Percentage & $100 \%$ & $57 \%$ & $43 \%$ & $100 \%$ & $51 \%$ & $49 \%$ \\
\hline
\end{tabular}

Fuente: Elaboración propia con motivos de esta investigación.

Table 2. Visibility/Omission: Visual and Textual Presentations of Females and Males

Book 2: Solutions Pre-Intermediate

\begin{tabular}{lcccccc}
\hline & \multicolumn{3}{c}{ Presentations in Illustrations } & \multicolumn{3}{c}{ Presentations in Texts } \\
\hline & Total & Female & Male & Total & Female & Male \\
Number & 61 & 31 & 30 & 206 & 95 & 111 \\
Percentage & $100 \%$ & $51 \%$ & $49 \%$ & $100 \%$ & $46 \%$ & $54 \%$ \\
\hline
\end{tabular}

Fuente: Elaboración propia con motivos de esta investigación. 
Tables 3 and 4, show the appearances of women and men in 10 scripted audios that were included in order to see the extent to which each gender was represented. The number of female and male characters was counted no matter how many times the character appeared in the scripts of the units under study.

Table 3. Number of Interventions in Dialogs (Listening Scripts)

Book 1: Teens in Motion 1

\begin{tabular}{|c|c|c|}
\hline & Female & Male \\
\hline Listening 1 (p. 17) & $\begin{array}{l}\text { The interviewer } \\
\text { ( } 7 \text { interventions) }\end{array}$ & $\begin{array}{l}\text { John a professional chef } \\
(1)\end{array}$ \\
\hline Listening 2 (p. 30) & $\begin{array}{l}\text { Physical therapist } \\
\text { (1 intervention) } \\
\text { News reader } \\
\text { (1 intervention) }\end{array}$ & $\begin{array}{l}\text { Miner (1) } \\
\text { Math teacher (1) }\end{array}$ \\
\hline Listening 3 (p. 39) & $\begin{array}{l}\text { Speaker } 1 \text { ( } 1 \text { intervention }) \\
\text { Speaker } 3 \text { (1 intervention) }\end{array}$ & Speaker $2(1)$ \\
\hline Listening 4 (p. 59) & Reporter (5 interventions) & $\begin{array}{l}\text { Sir Tim Berners-Lee ( } 5 \\
\text { interventions) }\end{array}$ \\
\hline Listening 5 (p. 72) & $\begin{array}{l}\text { Speaker } 1 \text { (1 intervention) } \\
\text { Speaker } 2 \text { (1 intervention) } \\
\text { Speaker } 3 \text { (1 interventions) }\end{array}$ & $\begin{array}{l}\text { Speaker } 4 \text { ( } 1 \text { intervention }) \\
\text { Speaker } 5 \text { ( } 1 \text { intervention }) \\
\text { Speaker } 6 \text { (1 intervention) }\end{array}$ \\
\hline Total & $19 / 36$ & $17 / 36$ \\
\hline Percentage & $53 \%$ & $47 \%$ \\
\hline
\end{tabular}

Fuente: Elaboración propia con motivos de esta investigación.

Table 4. Number of Interventions in Dialogs (Listening Scripts)

Book 2: Solutions Pre-Intermediate, Workbook

\begin{tabular}{lll}
\hline & Female & Male \\
\hline Listening 1 & Speaker 2 (1 intervention) & Speaker 1 (1 intervention) \\
Workbook (p. 8) & Speaker 4 (1 intervention) & Speaker 3 (1 intervention) \\
\hline Listening 2 & Ellie (4 interventions) & Ben (4 interventions) \\
Workbook (p. 10) & Daisy (4 interventions) & Leo (4 interventions) \\
& Molly (4 interventions) & James (4 interventions) \\
\hline
\end{tabular}




\begin{tabular}{|c|c|c|}
\hline $\begin{array}{l}\text { Listening } 3 \\
\text { Workbook (p. 10) }\end{array}$ & $\begin{array}{l}\text { Sophia (8 interventions) } \\
\text { Maisie (8 interventions) } \\
\text { Emma (7 interventions) } \\
\text { Alice (6 interventions) }\end{array}$ & $\begin{array}{l}\text { Charlie ( } 7 \text { interventions) } \\
\text { Daniel ( } 7 \text { interventions) } \\
\text { Luke ( } 6 \text { interventions) } \\
\text { George ( } 6 \text { interventions) }\end{array}$ \\
\hline $\begin{array}{l}\text { Listening } 4 \\
\text { Workbook (p. 18) }\end{array}$ & $\begin{array}{l}\text { Speaker } 1 \text { ( } 1 \text { intervention) } \\
\text { Speaker } 3 \text { ( } 1 \text { intervention) } \\
\text { Speaker } 4 \text { ( } 1 \text { intervention) } \\
\text { Amy ( } 3 \text { interventions) } \\
\text { Sam (4 interventions) } \\
\text { Lucy (5 interventions) }\end{array}$ & $\begin{array}{l}\text { Speaker } 2 \text { ( } 1 \text { intervention) } \\
\text { Ben ( } 5 \text { interventions) }\end{array}$ \\
\hline $\begin{array}{l}\text { Listening } 5 \\
\text { Workbook (p. 22) }\end{array}$ & ---- & Speaker 1 (1 intervention) \\
\hline Total & $58 / 105$ & $47 / 105$ \\
\hline Percentage & $55 \%$ & $45 \%$ \\
\hline
\end{tabular}

Fuente: Elaboración propia con motivos de esta investigación.

When it comes to character mentions in texts, the results of the two textbooks are very similar. Teen in Motions 1 has $53 \%$ of female mentions and $47 \%$ of male character mentions; Solutions-Pre Intermediate (workbook) has $55 \%$ of female mentions and $45 \%$ of male mentions, as illustrated in Table 3 and 4 . When it comes to visibility, both ELT textbooks represent female and male characters in listening scripts almost equally. However, the characters' occupations in Teens in Motion 1 are clear examples of gender bias, as the male characters are professionals (chef, miner, math teacher) or experts in a specific area as is the case of Sir Tim Berners-Lee on page 59 (Figure 1). Conversely, female characters are regarded as minor and less important roles such as speakers and interviewers. The words in bold in Table 3 (professional chef, Miner and Math teacher) show the relevance that professions have in a male-dominated world and it is taken for granted that men work and support the family and that women are depicted in secondary roles or unnecessary roles such as "speaker", "reporter", "news reader" or "interviewer" (see Table 3). 


\section{Figure $1^{1}$.}

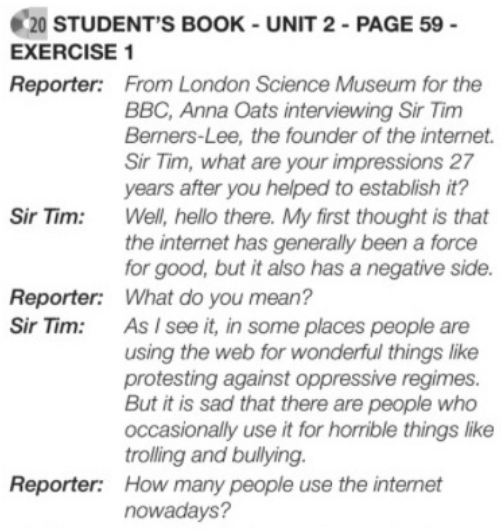

\author{
Sir Tim: Recent statistics say that $47 \%$ of the \\ world population uses the internet. \\ Millions use it every single day. In Asia \\ alone 1.6 billion people use it. 600 \\ million in Europe. 10 thousand new \\ internet applications are invented \\ each year. There are, on average, 40 \\ thousand google searches per second! \\ That's a lot of learning in a very short \\ time! \\ Reporter: It is amazing! \\ Sir Tim: $\quad$ Yes it is. The internet has changed the \\ way we communicate and learn. We can \\ communicate and learn wherever we \\ are and whoever we are - a student, a \\ teacher, an actress - we can all use the \\ internet for lifelong learning. \\ Reporter: And what brings you here today? \\ Sir Tim: I'm here to view an important part of
}

\subsubsection{Firstness}

Mention of men first in texts before women. To investigate gender firstness in school textbooks, the present study examined all the instances in the two textbooks in which the two genders were mentioned together and examined which appeared first. The findings are presented in Tables 5 and 6 below.

Table 5. Firstness: The Number of Times When Females or Males are Presented First in Texts or Sentences

Book 1: Teens in Motion 1

\begin{tabular}{lll}
\hline & Female First & Male First \\
\hline Instances & (p.43) ...my mom and dad. & (p.11) ...his/her turn. \\
& (p.75) Amanda and Rob. & (p.13) ...him/her meet... people. \\
& (p.14) ...he/she must have. \\
& (p.14) will he or she need any \\
& experience? \\
& (p.15) will you offer him/her? \\
& (p.19) ...his/her presentation.
\end{tabular}

${ }^{1}$ Polk, J. (2017). Teens in motion 1, Primero medio: Student's Book. (p. 59). Santiago: Ediciones Cal y Canto. 


\begin{tabular}{ll} 
& (p.38) ...his or her own free will \\
& without payment. \\
& $(\mathrm{p} .38) \ldots$ he/she has nothing else \\
& to do. \\
& $(\mathrm{p} .38) \ldots$ his or her own free will... \\
& $(\mathrm{p} .39)$ his/her recent arrival \\
& home? \\
& $(\mathrm{p} .45) \ldots$...he/she can use it. \\
& $(\mathrm{p} .45) \ldots$ himself/herself in XX \\
& years 'time. \\
& $(\mathrm{p} .63) \ldots$ men/women? \\
& $(\mathrm{p} .63) \ldots$. men and women... \\
& $(\mathrm{p} .66)$ Bill and Melinda Gates... \\
& $(\mathrm{p} .77)$ Bob and Ellen Sanchez. \\
& 16 \\
\hline Total &
\end{tabular}

Fuente: Elaboración propia con motivos de esta investigación.

Table 6. Firstness: The Number of Times When Females or Males are Presented First in Texts or Sentences

Book 2: Solutions Pre-Intermediate

\begin{tabular}{|c|c|c|}
\hline & Female First & Male First \\
\hline Instances & $\begin{array}{l}\text { (p.4) ...Iizzy and Ryan meet... } \\
\text { (p.4) ...Becky and Ryan } \\
\text { meet... } \\
\text { (p.24) Kate and Dan } \\
\text { (Audio Script, Workbook, } \\
\text { p.60) My mum and dad... (x2) }\end{array}$ & $\begin{array}{l}\text { (p.4) Ryan and Becky... } \\
\text { (p.6) He/She's got... } \\
\text { (p.10) My grandfather married } \\
\text { my grandmother in... } \\
\text { (p.11) ...Him/her. } \\
\text { (p.24) Dan and Kate... (x10) }\end{array}$ \\
\hline Total & 5 & 15 \\
\hline
\end{tabular}

Fuente: Elaboración propia con motivos de esta investigación.

As can be observed in Table 5 and 6, when pairs of female and male are introduced, men are most often mentioned first. This is the case in Book 1, with 16 (89\%) first mentions of males; while only $2(11 \%)$ cases of first mentions of females were observed. Likewise, Book 2, which is supposed to be aligned with the international conventions of inclusivity, features 15 (75\%) first mentions of males, and only 5 (25\%) first mentions of females. Thus, it can be seen that firstness is much evident in these four units, making it clear that 
males are more active and females more passive in the examples shown above. Similarly, Hartman and Judd (1978) argued that "such automatic ordering reinforces the second-place status of women and could, with only a little effort, be avoided by mixing the order" (p. 390). Despite the efforts the school texts developers have made to portray women and men equally, the findings indicated that men continue to be the protagonists and women are relegated to secondary places.

\subsubsection{Occupations, Roles and Activities}

Tables 7 and 8 below present a summary of the most representative occupations and or roles that females and males are often associated within the texts. The occupations or activities in bold, on the one hand, are common activities performed by males and females throughout the units from books 1 and 2, and on the other hand, are occupations or activities that called the attention of the researcher.

Table 7. Occupations and Roles: Occupations of Female and Male Characters in Texts and Pictures

Book 1: Teens in Motion 1

\begin{tabular}{lll}
\hline & Female & Male \\
\hline Pictures & (p.6) Doctor & (p.10) Musician \\
and Texts & (p.6) Builder & (p.14) Actor \\
& (p.10) Handcraft artist & (p.17) Professional Chef \\
& (p.14) Waitress & (p.21) Doctor \\
& (p.14) Seamstress & (p.30) Miner \\
& (p.14) Postwoman & (p.30) Math teacher \\
& (p.17) Interviewer & (p.34) Cobbler \\
& (p.21, p.35) Mechanics & (p.34) Bonesetter \\
& (p.30) Physical thera- & (p.35) Barrel organ player \\
pist & (p.39, p.64, p.76) Computer engineer \\
& (p.35) Clay artist & (p.43) Employer \\
& (p.35) Female barrel & (p.44) Film stuntman \\
& organ player & (p.48) Science teacher \\
& (p.39) Volunteer & (p.59) Founder of internet \\
& (p.44) Flight attendant & (p.66) History teacher \\
& (p.48) School teacher & (p.69) American football player
\end{tabular}




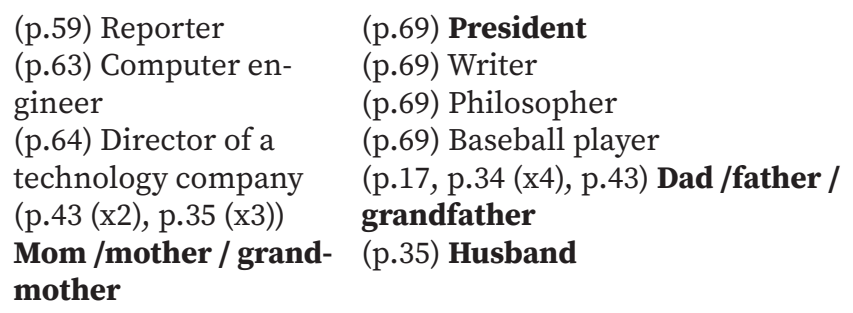

Fuente: Elaboración propia con motivos de esta investigación.

Table 8. Occupations and Roles: Occupations of Female and Male Characters in Texts and Pictures

Book 2: Solutions Pre-Intermediate

\begin{tabular}{lll}
\hline & Female & Male \\
\hline Pictures & (p.5) Guitarist & (p.5) Guitarist \\
and Texts & (p.7, p.13, p.14, p.20 & (p.5) Driver \\
& (x2)) Mum & (p.7, p.13) Dad \\
& (p.7) Teacher & (p.7, p.10) Math teacher \\
(p.9) Cooker & (p.10) Refuse collector \\
& (p.10) Grandmother & (p.10) Grandfather \\
& (p.10) Wife & (p.10) Millionaire \\
(p.21) Sportswoman & (p.14, p.15) Medical doctor \\
(p.60 workbook) & (p.18, p.19, p.22) Explorer \\
Mum (x2) & (p.20) Workmen \\
& (p.22) Sailor \\
& (p.24) Captain \\
& (p.24) Farm worker \\
& (p.21, p.23, p.26, p.27) Adventurer \\
& (p.28) Soldier \\
& (p.28) Traveller \\
& (p.28) Runner \\
& (p.28) Pilot \\
& (p.29) Biker \\
& (p.57 Audio Script, Workbook) Pianist \\
& (Audio Script, Workbook, p.58) Basket- \\
& ball player \\
& (p.58 Audio Script, Workbook) Science \\
& teacher \\
& (p.60 Audio Script, Workbook) Dad (x2) \\
&
\end{tabular}

Fuente: Elaboración propia con motivos de esta investigación. 
At first sight, one makes think those texts promote that gender gap becomes less relevant and portrays women into occupations such as mechanic (Figure 2), director of a technology company or builder. Furthermore, it may also be observed in table 7 and 8; males are portrayed as the figures that display power or the dominant role. As a way of illustration, the president happens to be a male (Figure 3). As we all know, a President is the most important figure of authority in a country and one that enjoys a good deal of political power. Other examples include: employers, captains, being a millionaire (Figure 4), and the founder of the Internet. As Porreca (1984) pointed out, men tend to occupy both more powerful and a greater range of occupational roles than women. All in all, in both school texts, the occupational roles assigned to females were the stereotypical ones of being a mother who gladly does jobs for free. Males were portrayed doing different occupations such as drivers, professors with different areas of specialization (history teachers, math teachers, and science teachers), engineers, musicians, etc. It is interesting to note that in both tables (7 and 8 ), there are few occupations performed by women that are similar to the occupations performed by men such as computer engineer (Figure 5), female barrel organ player, and doctor. However, as it can be observed that the number of occurrences of men who performed occupations such as computer engineers ( 3 times mentioned v/s 1 example referring to a woman), math teachers or science teachers, (4 times mentioned v/s 0 examples referring to women) is greater than the same occupations performed by women. On the contrary, females tend to be portrayed as having second rate roles and occupations such as waitress, and seamstress, and clay artists (Figure 6) or highly feminine roles as is the case of being mother (mentioned 13 times) or wife.

\subsubsection{Gendered Words and De-Gendered Words}

The data about gendered words and de-gendered words are presented in Tables 9 and 10. As it was mentioned previously, grammatical gender words are (gendered words and de-gendered words) 
Figure ${ }^{2}$.

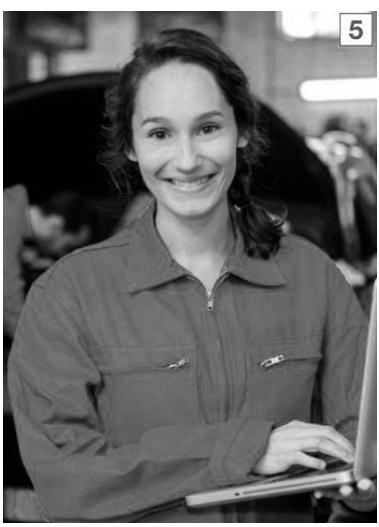

Figure $3^{3}$.

"Physical fitness is not only one of the most important keys to a healthy body: intellectual ac dynamic and creatioe John F. Kennedy

\section{Figure $4^{4}$.}

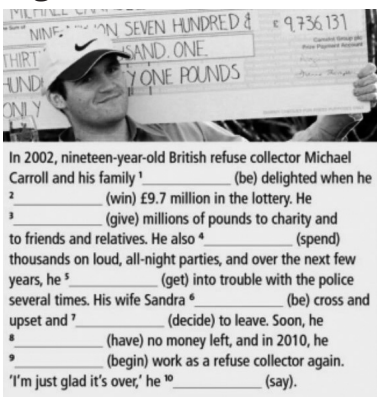

Figure $5^{5}$.

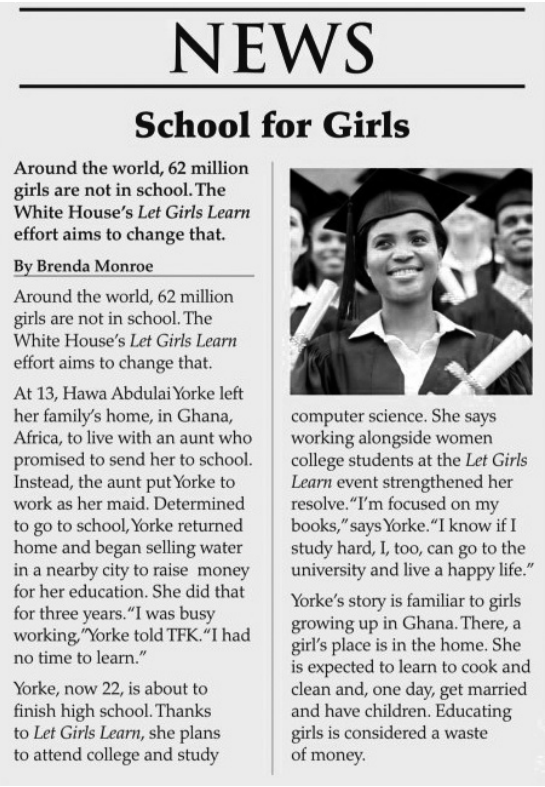

Figure $6^{6}$.
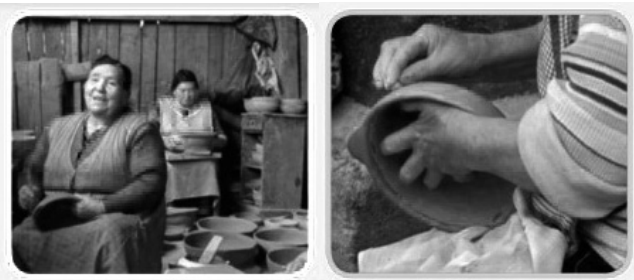

${ }^{2}$ Polk, J. (2017). Teens in motion 1, Primero medio: Student's Book. (p. 21). Santiago: Ediciones Cal y Canto.

${ }^{3}$ Polk, J. (2017). Teens in motion 1, Primero medio: Student's Book. (p. 69). Santiago: Ediciones Cal y Canto.

${ }^{4}$ Davies P. and Falla T. (2017). Solutions 3rd Edition Pre-Intermediate: Student's Book.(p. 10). España: Oxford University Press.

${ }^{5}$ Polk, J. (2017). Teens in motion 1, Primero medio: Student's Book. (p. 63). Santiago: Ediciones Cal y Canto.

${ }^{6}$ Polk, J. (2017). Teens in motion 1, Primero medio: Student's Book. (p. 35). Santiago: Ediciones Cal y Canto. 
words used to classify three gender categories; masculine, feminine, and neuter. This category of analysis is more illustrative of how language is used to perpetuate notions of sexism understood as "the stereotyping of males and females on the basis of their gender" (Renner, 1997, p. 2). As mentioned in earlier, the English language is sexist for two reasons: it reinforces gender and it makes that the masculine gender the norm in language. In this respect, Vogli (2009) remarks that: linguistic sexism in English has been identified in the pronouns ('generic' he, him etc.), generic 'man' which is used to denote not only the male but the humanity as a whole, as well as a suffix to form occupational terms (e.g. fireman), masculine and feminine equivalents where the feminine has sexual connotations (e.g. master-mistress) male firstness (e.g. John and Mary), suffixes -ess (e.g. waitress) which can only denote a woman, and titles used for men and women (Mr. vs. Mrs. and Miss) (p. 5).

Tables 9 and 10 show a summary of some of the words that are often used to express a gender or de-gendered occupation and roles in Teens in Motion 1 and Solutions Pre-Intermediate.

Table 9. Gendered Words and De-Gendered Words

Book 1: Teens in Motion 1

\begin{tabular}{ll}
\hline Gendered Words & De-Gendered Words \\
\hline (p. 14) Actor & Flight attendant \\
(p. 14, p.36) Waitress & Police officer \\
(p. 14) Postwoman & Lawyer \\
(p. 14) Seamstress & Doctor \\
(p. 14) Hostess & Dentist \\
(p. 26) Master distiller (a person or company that produ- & Scientist \\
ces strong alcoholic drinks (such as whiskey) by distilling & Singer \\
them) & Translator \\
(p. 26) Raven master (A Yeoman Warder responsible for the & Researcher \\
feeding and welfare of the ravens of the Tower of London) & Hairdresser \\
(p. 35) Female barrel organ player & \\
(p. 35) Husband & \\
(p. 44) Film stuntman & \\
(p. 71) Pretty & \\
(p. 17) Young man & \\
\hline
\end{tabular}

Fuente: Elaboración propia con motivos de esta investigación. 
Table 10. Gendered Words and De-Gendered Words

Book 2: Solutions Pre- Intermediate

\begin{tabular}{ll}
\hline Gendered Words & De-Gendered Words \\
\hline (p. 20) Workmen & Tourist \\
(p. 21) Sportswoman & Street vendor \\
& Police officer \\
\hline
\end{tabular}

Fuente: Elaboración propia con motivos de esta investigación.

It can be observed that the number of gendered words is remarkably larger than would have been expected. It is also interesting to note that gendered words in occupations continue to be used as is the case of 'waitress' which appeared twice on pages 14 and 36 in book 1, or 'hostess'. In this respect, Mustedanagic (2010) argues that the use of gendered words in different activities reflects that "a number of occupations are still dominated by men" and calls this distinction "gender prototype", which suggests that some occupations are to be performed by men and others by women (p. 40). The most obvious stereotype ("prototype") is a male doctor and a female nurse. This certainly does not mean that women cannot be employed as doctors or men as nurses, but that this is the general understanding introduced to us early on by society.

In response to the first research question, to what extent does the language used in English Language textbooks used by eleventh grade students in Chile suggest notions of sexism?, it can be claimed that ELT school books reflect sexist language that promote certain attitudes in society and can potentially impact students' learning.

The acquisition of the English language depends on their proficiency and their ability to negotiate with the new culture. As it was mentioned previously, English language is sexist (Hyde, 1984, Parks \& Roberton, 1998), it is a fact that English language learning would transfer sexism to students. 


\subsection{Research Question 2: How the Images Portray Gender Stereotypes}

For the purpose of answering the second research question dealing with how gender is portrayed in illustrations contained in English Language textbooks used by eleventh-grade students in Chile, the author made use of the principles that underpin socio-semiotics. Following Kress and van Leeuwen (2016), socio-semiotics serves the purposes of unraveling meanings through the use of graphic representations as meanings can be constructed not only verbally textua1ly, but also through illustrations. In the same vein, Kress and van Leeuwen (1996) argued that visual images are often (wrongly) treated as "decoration", or are dismissed altogether; however, ELT coursebooks do not only contain text and language rules to be learned; they also contain a number of images whether real or illustrated, which can have a powerful impact on language learners as is the case this study at hand.

The analysis was conducted by examining the images from each of the units randomly selected. Images containing females, males, advertisements, signs and so on were only examined if images showed up clearly. The analysis was made following these coding categories: The participants in each image (who); the actions that people perform (what is happening); and the circumstances (where) shown, following van Leeuwen's (2016) model. Other categories included are hair length (long hair, below the shoulders/short hair, if it just reaches the neck), clothes color (light colors for female or dark/opaque colors for male) and feminine clothing (skirts, dresses and trousers), and facial features. This analysis is informed by three main studies: Yasin, Hamid, Othman, Bakar, Hashim, and Mohti (2012), who addressed gender biases in visual images of Malaysian English school textbooks; Ahmed's study (2012), who examined "the iconic representation of women in the middle Eastern media in order to determine how various semiotic resources have been utilized in conveying specific messages to a given audience" (p. 1); and finally, Ruby's research (2016), who conducted a study that involved a visual (semiotic) analysis of how gender is represented in illustrations of ELT books in terms of their hair length and clothing. 
The analysis of images is done through the lens of critical theory in order to determine how such graphic elements construct meanings whereby one gender is portrayed as the dominant and another one as dominated. As a summary, the analysis is done around four main themes, which emerged as the author analyzed the available data. These are: (i) Obvious femininity, (ii) Women doing menial work or unskilled jobs, (iii) Women attempting to make their way into male-dominated domains, and (iv) Successful and powerful men.

\subsubsection{Obvious Femininity}

There are figures in the four units that were selected which are very indicative of an attempt to portray women as evidently feminine. Following van Leeuwen's (2016) model, Figure 7 shows a group of girls ("who") dressed in pink, which is always associated with being a girl; all of them have long hair; some of them are wearing hairpins or a headpiece; they are sitting on the floor. It also can be observed that the girls are playing with a robotic dog ("what is happening"). All of these meanings found in Figure 7 are traits traditionally attributed to women in society. This corroborates what the literature suggests in that femininity is often thought as "compassionate, supportive, and relationship oriented (DeFrancisco \& Palczewski, 2007, p. 10).

The same thing happens in Figure 8, from where two white girls ("who") showing happiness can be seen probably out of academic achievement demonstrating support, care, and concern for her friend ("what is happening"). Once again, women are depicted with long hair, wearing clothing decorated with flower patterns and the girl placed on the right hand has her nails clean, cared for and polished. For some years now people have heard that women are always nicely dressed and arranged, and Figure 8 comes to ratify this gender stereotype. 
Figure $7^{7}$.

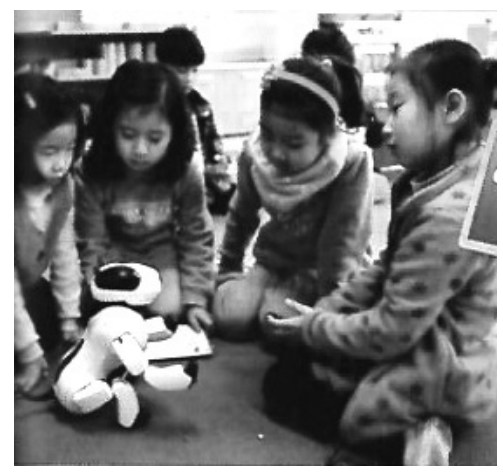

Figure $8^{8}$.

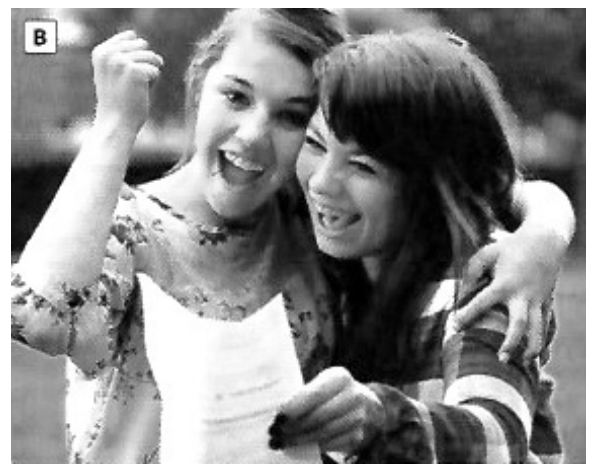

\subsubsection{Women Doing Menial Work or Unskilled Jobs}

In the four units selected for the purpose of this study, some graphic images and representations portray women as linked to menial work. Figure 9, for instance, shows women ("who") doing handmade products. The woman in the foreground seems content with what she is doing; the woman in the background appears to be focused on her work looking down on the manufacturing process ("what is happening"). The picture shows in the foreground several pots which are apparently made by the women in the workshop ("where"). The place seems rather rudimentary and kept in pretty bad shape. In addition, the women are wearing colors most commonly associated with femininity. Accordingly, Cameron (2001) argues that sexism is defined "as a negative attitude or discriminatory behavior based on the presumed inferiority or difference of women as a group" (as cited in Sakalli, 2001, p. 601) since women have been traditionally portrayed as responsible for raising children, full-time housewives (much less than before), with limited professional development and career prospects.

${ }^{7}$ Davies P. and Falla T. (2017). Solutions 3rd Edition Pre-Intermediate: Student's Book. (p. 7). España: Oxford University Press.

${ }^{8}$ Davies P. and Falla T. (2017). Solutions 3rd Edition Pre-Intermediate: Student's Book. (p. 8). España: Oxford University Press. 
The same is shown in Figure 10, a working woman ("who") selling stuff on the street ("what is happening" / "where"). These stuff are low cost products that offer little pay or opportunity for advancement.

Figure $9^{9}$.

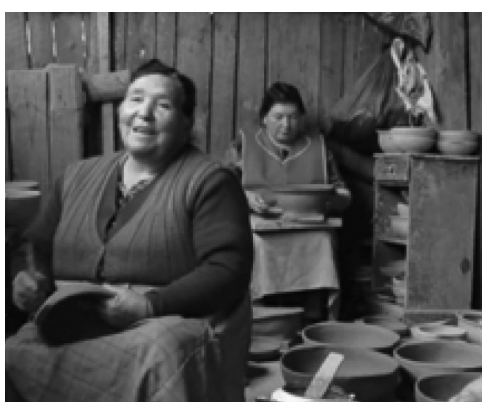

Figure $10^{10}$.

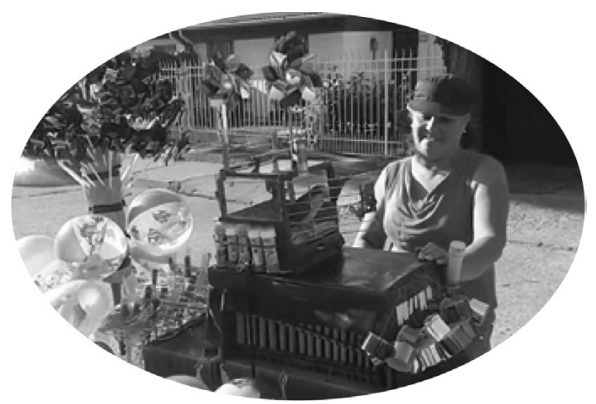

5.2.3 Women Attempting to Make Their Way Into Male Dominated Domains

As can be seen in Figure 11, the woman ("who") on the left hand side is engaged in office related activities ("where") sitting at her desk and wearing a male like suit. However, she does not abandon her femininity as she has long hair, which is often socially perceived as a sign of a feminine look. The same phenomenon can be observed in Figure 12, where there is a superficial attempt to show the woman being incorporated into a male-dominated domain, in this case being a mechanic ("who"); however she has a flawless face and spotless hands; she is clean and tidy, with her hair nicely combed and a big smile on her face; her hair is long, she is white blond. She is holding a computer in her hands, while in the background you see a more realistic portrayal of a mechanic working on a car, who happens to be a man ("what is happening"). Similarly, Figure 13

${ }^{9}$ Polk, J. (2017). Teens in motion 1, Primero medio: Student 's Book. (p.35). Santiago: Ediciones Cal y Canto.

${ }^{10}$ Polk, J. (2017). Teens in motion 1, Primero medio: Student's Book. (p.35). Santiago: Ediciones Cal y Canto. 
shows a woman dressed as a builder ("who") but without any tools in her hands. As in Figure 11, she is wearing male like clothing but her appearance is neat and classy. As a conclusion, from these images it can be observed that women are portrayed around the theme of making their way into male-dominated domains as is the case of office environment, mechanic, and engineering but, as Trujillo (1991) suggested, there is a hegemonic masculinity in society that includes "power defined in terms of physical force and control, success defined in terms of occupational achievement in traditionally male jobs, familial patriarchy, presenting a "frontier" image, and heightened heterosexuality" (pp. 291-292). In other words, to be valued in society it is necessary to follow male patterns having in mind that women will be in subordinate positions.

Figure $11^{11}$.

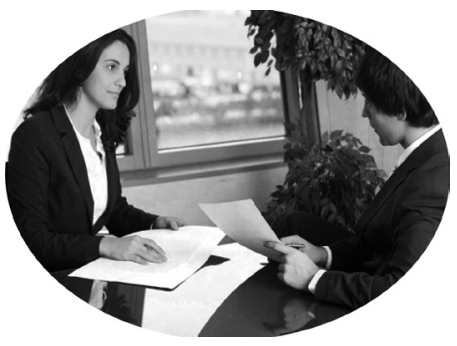

Figure $12^{12}$.

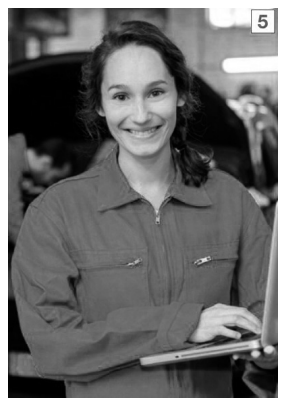

Figure $13^{13}$.

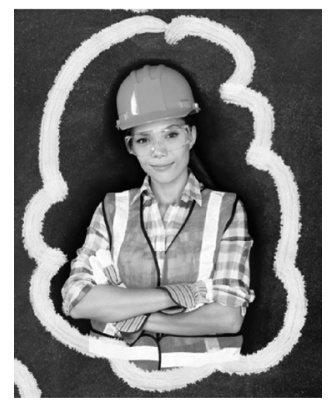

\subsubsection{Successful and Powerful Men}

In general, women are seen as less important than men in all aspects of life, while males are seen as more inspirational, successful, intellectually capable and more rational than females (Martell

${ }^{11}$ Polk, J. (2017). Teens in motion 1, Primero medio: Student's Book. (p. 23). Santiago: Ediciones Cal y Canto.

${ }^{12}$ Polk, J. (2017). Teens in motion 1, Primero medio: Student's Book. (p. 21). Santiago: Ediciones Cal y Canto.

${ }^{13}$ Polk, J. (2017). Teens in motion 1, Primero medio: Student's Book. (p. 6). Santiago: Ediciones Cal y Canto. 
\& DeSmet, 2001). As can be seen in Figure 14, a professional chef (a man) is shown as a rich and powerful individual ("who"); he is so well-known that he is getting ready for another world tour and has his own private jet waiting on the tarmac ("what is happening"). From Figure 15 a young medical doctor ("who") can be observed that continues the work of Patch Adams who is an internationally renowned American doctor who promoted Laughter Therapy during the 1970s. He has short hair; he is wearing a tie that gives him a distinctive look and has got a beard which is associated with masculinity. As the literature suggests, very often "people perceive men as being highly competent, men are more likely to be considered leaders, given opportunities, and emerge as leaders than women" (Pienpeg, 2008, p. 22). It is assumed that women find themselves in disadvantaged positions and have to make greater efforts to succeed in a male dominated world.

Figure 14 ${ }^{14}$.

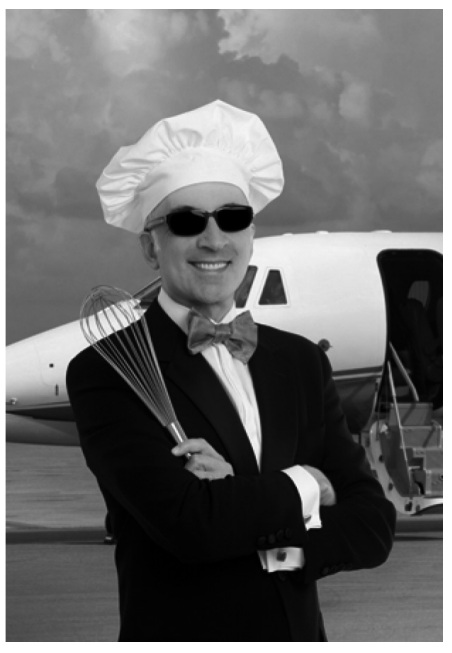

Figure $15^{15}$.

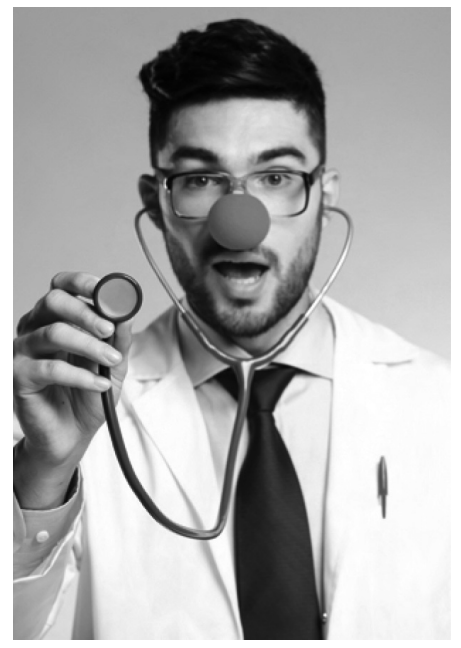

${ }^{14}$ Polk, J. (2017). Teens in motion 1, Primero medio: Student's Book. (p. 21). Santiago: Ediciones Cal y Canto.

${ }^{15}$ Polk, J. (2017). Teens in motion 1, Primero medio: Student's Book. (p. 21). Santiago: Ediciones Cal y Canto. 


\section{Conclusions, Limitations, and Suggestions for Further Research}

As a number of previous studies have already shown, a male bias in categories such as visibility and firstness is presented in this study. Both books, Teens in Motion (book 1) and Solutions Pre-Intermediate (book 2), showed that the number of male appearances in texts or images exceeds the number of female appearances, despite the fact that publishing houses make efforts to make gender discrimination less noticeable. Moreover, the male presence continues to be conveyed as the powerful one. The most common reason for this is that people live in a male-dominated world, which is why male characters are portrayed with more or lengthy interventions in dialogs and texts, occupying important positions, taking decisions, etc. It should be noted that in the firstness category, the representation of males was significantly more evident, making it clear that males are more active and females more passive in both school texts.

Prominent in this analysis is that the stereotypical gender roles of wives and mothers are assigned to women and that they are largely confined to the private world at home and work for free. In Teens in Motion and Solutions Pre-Intermediate males are portrayed as the figures that display power or the dominant role (captain, millionaire, president), as well as adventurous and active people (Figures 16 and 17). It must be taken into account that in both coursebooks, women are portrayed in mostly traditional domestic and social roles such as mother, grandmother, and wife, cooker, teacher (Figure 18), artist, volunteer (Figure 19). Giving equal prominence to females and males in the representation of occupations and/or roles in ELT textbooks (images as well as text) may encourage females to consider a full range of possibilities in different spheres of society.

A great number of gendered words were found in Teens in Motion 1 book, which was not the case in the Solutions Pre-Intermediate book, where hardly any gendered words could be found. When examining the language in Teens in Motion 1, it is obvious that there is a tendency to separate words where a distinction is made whether you are a female or male, such as waitress, actor, and hostess. 


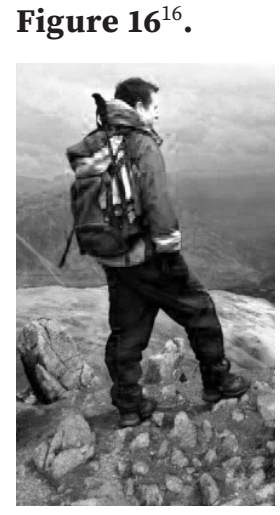

Figure $18^{18}$.

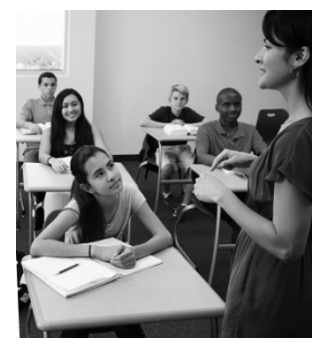

Figure $17^{17}$.

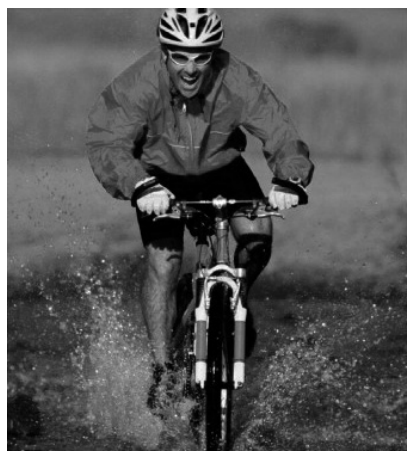

Figure $19^{19}$.

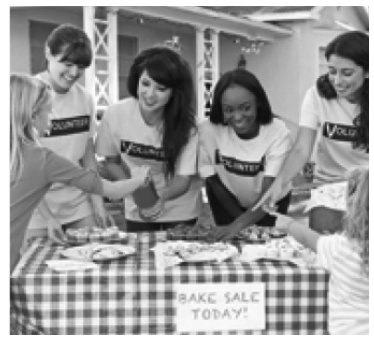

Teens in Motion 1 contained a frequent usage of the affix -man and the word master such as film stuntman, master distiller, raven master, young man, etc. (Teens in Motion 1, 2017; 26-44-17).

One could also notice a tendency to make the distinction between activities performed by men and others performed by women, as well as words (activities) using the affix -ess or -women, for example in waitress, seamstress and hostess, postwoman, female barrel

${ }^{16}$ Davies P. and Falla T. (2017). Solutions 3rd Edition Pre-Intermediate: Student's Book. (p. 18). España: Oxford University Press.

${ }^{17}$ Davies P. and Falla T. (2017). Solutions 3rd Edition Pre-Intermediate: Student's Book.(p. 29). España: Oxford University Press.

${ }^{18}$ Polk, J. (2017). Teens in motion 1, Primero medio: Student's Book. (p. 48). Santiago: Ediciones Cal y Canto.

${ }^{19}$ Polk, J. (2017). Teens in motion 1, Primero medio: Student's Book. (p. 39). Santiago: Ediciones Cal y Canto. 
organ player (Teens in Motion 1, 2017; 14-35-36). Renner (1997) claimed that teaching pupils that a police officer is called a "policeman" can, from this perspective, be seen as contributing to the creation of gender roles which separate males and females and restrict them occupationally (p. 3-5). Inclusive language aims at the purpose to not make assumptions regarding gender. This may include a change concerning gendered vocabulary into a more inclusive one, creating a friendly atmosphere for women and men in the classroom, promoting equal opportunities for all individuals.

In a similar vein, the images analyzed in this study revealed a clear gender imbalance in favor of males mostly. All the images examined present females in disadvantaged positions (poverty or subordinate positions) and having to make greater efforts to succeed in a male-dominated world. Something interesting is the fact that in order to be considered in a job, it is necessary to follow male patterns such as wearing a suit. On the contrary, males are depicted as rich and powerful individuals, young, attractive, and occupying important roles. An efficient gender perspective must be urgently developed for ELT textbooks since there is an absence of positive female role models for girls to identify with (Yasin et al., 2012). Gender stereotypes are presented in illustrations and they impact students' perception about their gender.

Some of the limitations that need to be acknowledged in this section deal with the very methodological approach used in the study which relates to the paradigmatic subjective interpretation of images. Thus, it can be argued that a good deal of what has been presented as findings respond to the researcher's own personal lens and standpoint. Also, the fact that only two coursebooks have been used for the study does not necessarily represent how materials are being put together these days, and how feminism and gender stereotypes are currently being dealt with by ELT textbooks developers. Also, it would be interesting to investigate how teachers deal with gender bias in ELT materials and how their ideologies can impact students. Also, research on gender issues in classroom interaction and curriculum is recommended. 


\section{Referencias}

Ahmed, S. (2012). A Semiotic Analysis of the Iconic Representation of Women in the Middle Eastern Media (Master of Arts in Applied Linguistics dissertation). University of Birmingham, UK.

Amini, M. \& Birjandi, P. (2012). Gender Bias in the Iranian High School EFL Textbooks. English Language Teaching, 5(2), 134-147.

Ansary, H. \& Babii, E. (2003). Subliminal sexism in current ESL/EFL textbooks. Asia EFL Journal, 5(1). Retrieved from http://www.asian-efljournal.com/march03.sub1.php

Barton, A. \& Sakwa, L. (2012). The Representation of Gender in English Textbooks in Uganda. Pedagogy, Culture \& Society, 20(2), 173-190.

Bell, P. (2001). Content analysis of visual images. In: Van Leeuwen, T, Jewitt, C. (Eds.), Handbook of Visual Analysis (pp. 10-34). London: Sage.

Brugeilles, C. \& Cromer, S. (2009). Promoting Gender Equality Through Textbooks: A Methodological Guide. Paris: United Nations Educational, Scientific and Cultural Organiztion.

Coates, J. (1986). Women, Men and Language. London: Longman.

Davies, P. \& Falla, T. (2017). Solutions 3rd Edition Pre-Intermediate: Student's Book. España: Oxford University Press.

DeFrancisco, V. \& Palczewski, C. (2007). Communicating gender diversity: A critical approach. Los Angeles, CA: SAGE Publications.

Emilia, E., Yunita, N. \& Laela I. (2017). Gender in EFL Classroom: Transitivity Analysis in English Textbook for Indonesian Students. Indonesian Journal of Applied Linguistics, 7(1), 206-214.

Etaugh, C. \& Bridges, J. (2010). Women's Lives: A Psychological Exploration. Boston: Allyn \& Bacon.

Gharbavi, A. \& Mousavi, S. (2012). A Content Analysis of Textbooks: Investigating Gender Bias as a Social Prominence in Iranian High School English Textbooks. English Linguistics Research, 1(1), 42-49.

Graham, A. (1975). The making of a non-sexist dictionary. In Thorne, B. \& Henley, N. (Eds.). Language and Sex, (pp.57-63). Rowley, Massachusetts: Newbury House Publishers, Inc.

Gray, L. (2002). The global coursebook in English language teaching. In Block, D. and Cameron (Eds.) Globalization and Language Teaching. (pp. 152-167). London: Routledge. 
Hamilton, M., Anderson, D., Broaddus, M. \& Young, K. (2006). Gender stereotyping and under-representation of female characters in 200 popular children's picture books: A twenty-first century update. Sex Roles, 55(1112), 757-765. Retrieved from http://link.springer.com/article/10.1007\%2Fs11199-006-9128-6\#page-1

Hartman, P. \& Judd, E. (1978). Sexism and TESOL materials. TESOL Quarterly, 12(4), 383-393.

Hellinger, M. (1980). "For men must work, and women must weep": sexism in English language textbooks used in German schools. In Kramarae, Ch. (Ed.). The Voices and Words of Women and Men (267-274). Elmsford, New York: Pergamon Press.

Hellinger, M. \& Bußmann, H. (2001). Gender Across Languages: The Linguistic Representation of Women and Men. Amsterdam: John Benjamins.

Hodkinson, H. \& Hodkinson, P. (1999). Teaching to learn, learning to teach? School-based non-teaching activity in an initial teacher education and training partnership scheme. Teaching and Teacher Education, 15(3), 273-285.

Hyde, J. (1984). Children's understanding of sexist language. Developmental Psychology, 20(4), 697-706.

Key, M. (1975). Male/Female Language. Metuchen, NJ.: The Scarecrow Press.

Kress, G. \& Van Leeuwen, T. (1996). Reading Images: The Grammar of Visual Design. London: Routledge.

Kress, G. \& Van Leeuwen, T. (2016). Multimodal Discourse: The Modes and Media of Contemporary Communication. London: Hodder Education.

Lakoff, R. (1975). Language and Woman's Place. New York: Harper and Row.

Manstead, A. \& Hewstone, M. (Eds.). (1995). The Blackwell Encyclopedia of Social Psychology. Oxford: Blackwell.

Martell, R. \& DeSmet, A. (2001). A diagnostic-ratio approach to measuring beliefs about the leadership abilities of male and female managers. Journal of Applied Psychology, 86(6), 1223-1231.

McGabe, J., Fairchild, E., Grauerholz, L., Pescosolido, B. \& Tope, D. (2011). Gender in Twentieth-Century Children's Books: Patterns of Disparity in Titles and Central Characters. Gender \& Society, 25(2),197-226.

Mineshima, M. (2008). Gender representations in an EFL textbook. Bulletin of Niigata Institute of Technology. Retrieved from: https://www.researchgate.net/publication/304011261_Gender_Representation_in_Primary_ English_Textbooks_in_Mainland_China_1978_to_2003 
Mukundan, J. \& Nimehchisalem, V. (2008). Gender representation in Malaysian secondary school English language textbooks. Indonesian Journal of English Language Teaching, 4(2), 155-173.

Mustedanagic, A. (2010). Gender in English language and EFL textbooks. A term paper Submitted to Halmstad University, Hogskola.

Nilsen, A. (1977). Sexism in children's books and elementary classroom materials. In Pace, A., Bosmajian, H., Gershuny, L. \& Stanley, J (Eds.). Sexism and Language (pp.161-179). Urbana, Illinois: National Council of Teachers of English.

Parham, F. (2013). Gender Representation in Children's EFL Textbooks. Theory and Practice in Language Studies, 3(9), 1674-1679.

Parks, J. \& Roberton, M. (1998). Contemporary arguments against non-sexist language: Blaubergs (1980) revisited. Sex Roles, 39, 445-461.

Pienpeg, N, P. (2008). An Analysis of Sexist Language in ESL Textbooks by Thai Authors Used in Thailand, Dissertation. [Paper submitted to UNT Digital Library, the University of North Texas as a course requirement for the Degree of Doctor of Philosophy]. Retrieved from https://digital.library. unt.edu/ark:/67531/metadc9057/m1/103/

Polk, J. (2017). Teens in motion 1, Primero medio: Student 's Book. Santiago: Ediciones Cal y Canto.

Porreca, L. (1984). Sexism in Current ESL Textbooks. TESOL, 18(4), 705-724.

Poulou, S. (1997). Sexism in the discourse roles of textbook dialogues. Language Learning Journal, 15, 68-73.

Rahimi, A. \& Sahragard, R. (2007). Critical Discourse Analysis. Tehran: Jungle Publications.

Renner, C. E. (1997). Women are "busy, tall, and beautiful”: Looking at sexism in EFL materials. Paper presented at the National Seminar "Mind the Language", Rome, Italy (1996) and at the Annual Meeting of the Teachers of English to Speakers of Other Languages, Orlando (1997).

Ruby, C. (2016). Are males and females still portrayed stereotypically? Visual analyses of gender in two Hong Kong primary English Language textbook series. Gender and Education, 28(5), 674-692.

Sakalli, N. (2001). Beliefs about wife beating among Turkish college students: The effects of patriarchy, sexism, and sex differences. Sex Roles, 44, 599-610. 
Trujillo, N. (1991). Hegemonic masculinity on the mound media representations of Nolan Ryan and American sports culture. Critical Studies in Mass Communication, 8, 290-308.

Van Leeuwen, T. (2008). Discourse and Practice: New Tools for Critical Discourse Analysis. New York: Oxford University Press.

Vogli, S. (2009). Gender representation in New Success at First Certificate. (Paper submitted to CELS as course requirement for the Degree of Master of Arts in Applied Linguistics). The University of Birmingham. Birmingham, UK. Retrieved from https://www.birmingham.ac.uk/Documents/college-artslaw/cels/essays/sociolinguistics/SotiVogliSO.pdf

Yasin, M., Hamid, B., Othman, Z., Bakar, K., Hashim, F. \& Mohti, A. (2012). A Visual Analysis of a Malaysian English School Textbook: Gender Matters. Procedia - Social and Behavioral Sciences, 69, 1871-1880.

Yonata, F. \& Mujiyanto, Y. (2017). The Representation of Gender in English Textbooks in Indonesia. Journal of Language and Literature, 12(1), 91-101. 